\title{
On the spider fauna of Bolshoy Aynov Island (Barents Sea) (Arachnida: Aranei)
}

\author{
К фауне пауков острова Бомьшой Айнов (Баренџево море) \\ (Arachnida: Aranei)
}

\author{
Anna A. Nekhaeva ${ }^{1}$ \& Ivan O. Nekhaev ${ }^{2}$ \\ А.А. Нехаева ${ }^{1}$, И.О. Нехаев ${ }^{2}$

\begin{abstract}
${ }^{1}$ Institute for Problems of Ecology and Evolution, Russian Academy of Sciences, Leninsky pr. 33, Moscow 119071 Russia. E-mail: Adrealinea@gmail.com

Институт проблем экологии и эволюции РАН, Ленинский пр. 33, Москва 119071 Россия. Russia. E-mail: inekhaev@gmail.com

Мурманский морской биологический институт КНЦ РАН, ул. Владимирская 17, Мурманск 183008 Россия.
\end{abstract} \\ ${ }^{2}$ Murmansk Marine Biological Institute, Kola Science Centre, Russian Academy of Sciences, Vladimirskaya str. 17, Murmansk 183008
}

KEY WORDS: Spiders, Kola Peninsula, tundra, island fauna.

КЛЮЧЕВЫЕ СЛОВА: Пауки, Кольский полуостров, тундра, островная фауна.

ABSTRACT. An annotated list of 17 spider species of 4 families based on personal collecting from Bolshoy Aynov Island (Varangerfjord, Barents Sea) is presented. Savignia frontata Blackwall, 1833 is recorded from the tundra zone of Kola Peninsula for the first time.

РЕЗЮМЕ. Приведен аннотированный список пауков острова Большой Айнов (Варангер-фьорд, Баренцево море), составленный на основе собственных сборов, и включающий 17 видов из 4 семейств. Savignia frontata Blackwall, 1833 впервые отмечен для фауны пауков тундровой зоны Кольского п-ова.

\section{Introduction}

Spider fauna of the Kola Peninsula is well documented by Tanasevitch, Rybalov [2010] and Tanasevitch, Kamayev [2011], whereas that of coastal islands is poorly known. Only two spider species Bolyphantes luteolus (Blackwall, 1833) and Pardosa palustris (Linnaeus, 1758) — have been recorded by Fedotov [1912] and Vasilyeva, Nekhaev [2009] from Bolshoy Aynov Island. Limited information on the spiders of adjacent Arctic territories of Norway was provided by Aakra et al. [2000].

This study is based on a small spider collection made by the second author on Bolshoy Aynov Island in 2008. The material is temporally stored in the personal authors' collection and will be passed in the Zoological Museum of the Moscow State University, Moscow.

\section{Study area, material and methods}

Bolshoy Aynov Island (Fig. 1) is situated in Varangerfjord, $5 \mathrm{~km}$ west of the Sredniy Peninsula, the SW part of Barents Sea. The Island is about $2 \mathrm{~km}$ long and represents a flat plain with the extensive boggy depression and numerous lakes in its SE part.

The studied area belongs to the Kola subprovince of the southern subarctic tundra [Aleksandrova, 1977], which is characterized by poor development of lichen and widespread undershrub communities alternated with swamps, peatbogs and anthropogenic meadows [Bereslina, 1987]. The island has no permanent human population, but rather a seasonal research station and lighthouse.

The material was collected from 12 localities (Fig. 2) during the period of 26 May - 26 June 2008 by pitfall traps (with $70 \%$ ethanol), soil sampling and hand collecting. Details of the collecting localities are as follows:

1. Meadow near the seashore, with Carex spp., Anthriscus silvestris, Angelica archangelica, dried grass, woody debris $\left(69^{\circ} 49,964^{\prime} \mathrm{N}, 31^{\circ} 34,059^{\prime} \mathrm{E}\right)$; pitfall traps under drift wood.

2. Meadow with stands of Anthriscus sp. and Angelica $\mathrm{sp} .\left(69^{\circ} 50,087^{\prime} \mathrm{N}, 31^{\circ} 33,807^{\prime} \mathrm{E}\right)$; pitfall trap in dried grass and woody debris.

3. Wetland with Salix sp. stands $\left(69^{\circ} 50,149^{\prime} \mathrm{N}\right.$, $\left.31^{\circ} 33,810^{\prime} \mathrm{E}\right)$; pitfall trap in woody debris and dried grass.

4. Undershrub tundra, with Empetrum hermaphroditum near lighthouse $\left(69^{\circ} 50,280^{\prime} \mathrm{N}, 31^{\circ} 33,798^{\prime} \mathrm{E}\right)$; pitfall trap in Polytrichum sp.

5. Meadow with Anthriscus sp. and Angelica sp., near bathhouse.

6. Anthropogenic meadow near the lighthouse.

7. Microdepression on slope with ferns, Rumex sp. and Empetrum hermaphroditum, near the lighthouse.

8. A well, from water surface.

9. Indoor. 


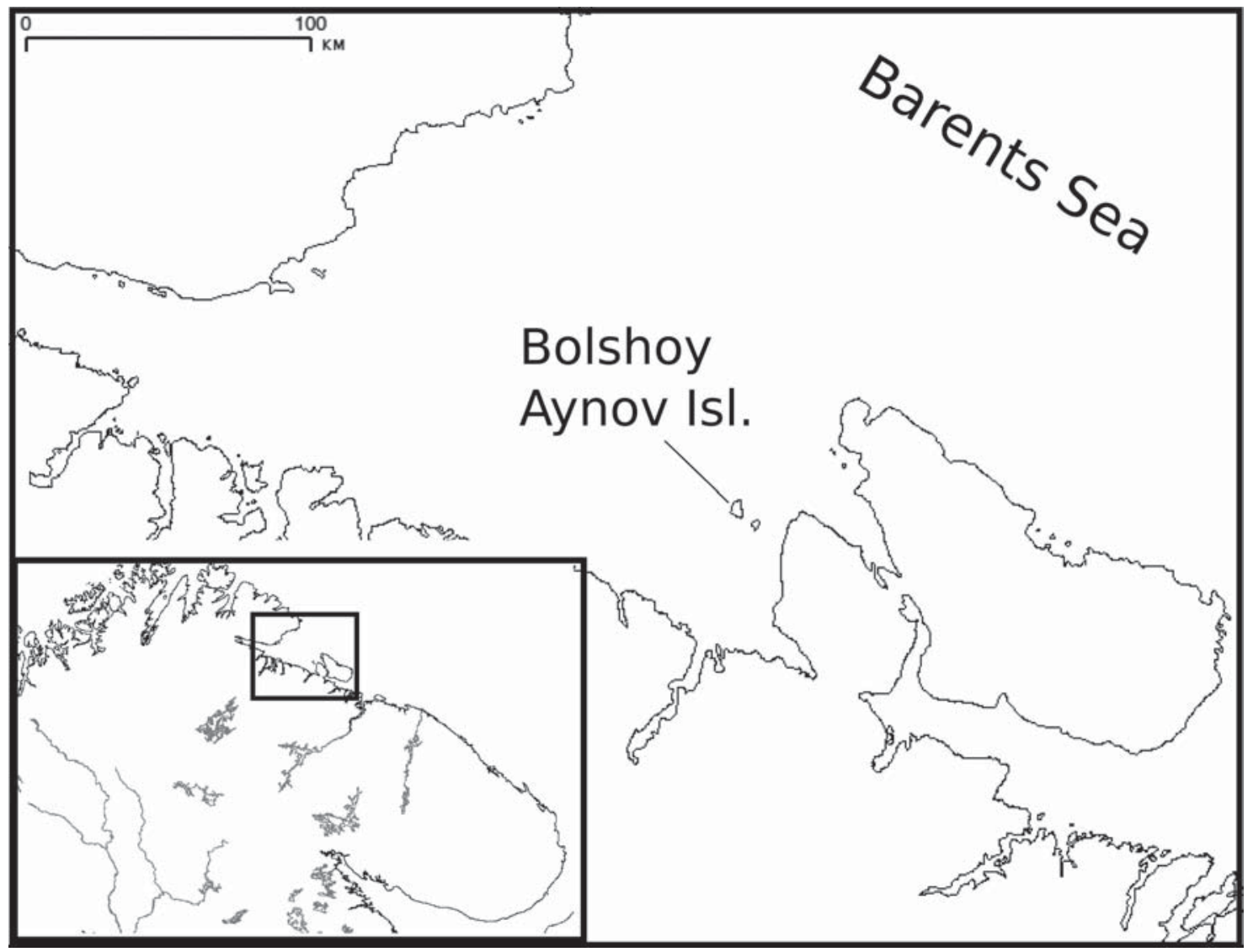

Fig. 1. Geographic location of Bolshoy Aynov Island.

Рис. 1. Месторасположение о-ва Большой Айнов.

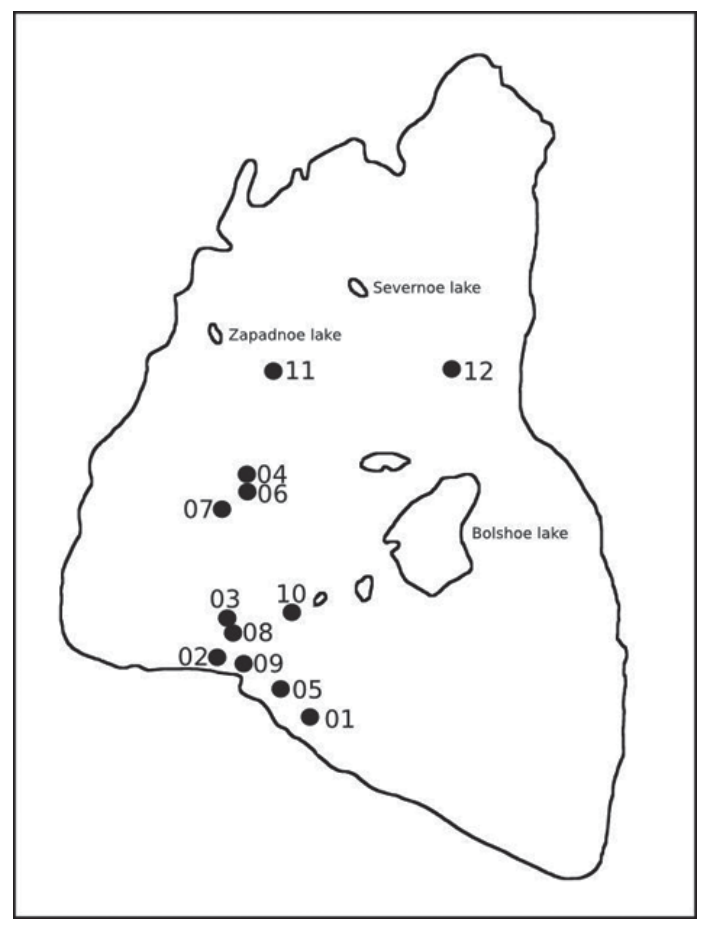

Fig. 2. Map of Bolshoy Aynov Island with collecting localities. Рис. 2. Карта о-ва Большой Айнов и точки сборов.
10. Peatbog, among dried grass and young spears $\left(69^{\circ} 50,104^{\prime} \mathrm{N}, 31^{\circ} 34,021^{\prime} \mathrm{E}\right)$.

11. Microdepression on slope with ferns, Rumex sp. and Empetrum hermaphroditum.

12. Meadow with Chamaepericlymenum suecicum, Rubus chamaemorus, Rumex sp. and Empetrum hermaphroditum.

In the following text, numbers in square brackets correspond to the aforementioned localities. Distributional species patterns follow Tanasevitch, Kamayev [2011].

\section{List of spiders}

\section{Fam. LINYPHIIDAE (14)}

Bathyphantes gracilis (Blackwall, 1841)

MATERIAL. 1 + [1], 6-9.VI.2008; 2 우, $10^{7}$, same locality, 13-15.VI.2008; 1 ㅇ, same locality, 15-17.VI.2008; 1 ㅇ [2], 1517.VI.2008; 1 + , 1 O', same locality, 17-20.VI.2008; 1 + [3], 2426.VI.2008

RANGE. Holarctic polyzonal.

Bolyphantes luteolus (Blackwall, 1833)

Bolyphantes luteolus. - Fedotov, 1912: 461.

MATERIAL. 1 ㅇ [1], 29-31.V.2008.

COMMENTS. This is one of the northernmost records of the species. 
RANGE. Palaearctic boreo-nemoral.

Centromerus arcanus (O.Pickard-Cambridge, 1873) MATERIAL. $1 \sigma^{7}$ [1], 15-17.VI.2008; $20^{7} \sigma^{7}$ [5], 24-25.VI.2008. COMMENTS. This is the northernmost record of the species.

RANGE. Palaearctic polyzonal.

Hilaira herniosa (Thorell, 1875)

MATERIAL. 2 우, $10^{7}$ [2], 31.V-2.VI.2008; 1 ㅇ [3], 1315.VI.2008.

RANGE. Holarctic boreal.

Hypomma bituberculatum (Wider, 1834)

MATERIAL. $2 \sigma^{7} \sigma^{7}$ [4], 9-11.VI.2008; $1 \sigma^{7}$, same, 1517.VI.2008; 2 우, same locality, 17-20.VI.2008; 2 우, same locality,

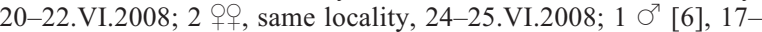
20.VI.2008; 3 우, same locality, 24-25.VI.2008.

RANGE. Palaearctic polyzonal.

Micrargus herbigradus (Blackwall, 1854)

MATERIAL. 1 ㅇ [2], 9-11.VI.2008; $10^{7}$, same locality, 1720.VI.2008.

COMMENTS. This is the northernmost record of the species.

RANGE. Palaearctic boreo-nemoral.

Oedothorax retusus (Westring, 1851)

MATERIAL 1 ㅇ [4], 4-6.VI.2008; 2 오, same locality, 1315.VI.2008; 1 क , same locality, 15-17.VI.2008; 1 + [6], 1720.VI.2008; 2 우, same locality, 20-22.VI.2008; 3 우, 1 O', same locality, 24-25.VI.2008.

RANGE. Palaearctic polyzonal.

Oreonetides vaginatus (Thorell, 1872)

MATERIAL. $1 \sigma^{7}$ [1], 6-9.VI.2008; 1 O $^{7}$, same, 11-13.VI.2008; $1 \mathrm{O}^{2}$, same, 17-20.VI.2008.

RANGE. Holarctic boreal.

Oryphantes angulatus (O.Pickard-Cambridge, 1881) MATERIAL. $1 \bigcirc^{7}$ [2], 4-6.VI.2008; 2 우, same locality, 1315.VI.2008; 1 + $1 \bigcirc^{7}$, same locality, 15-17.VI.2008; $1 \sigma^{7}$ [6], 24 25.VI.2008.

COMMENTS. This is one of the northernmost records of the species.

RANGE. European boreo-nemoral.

Savignia frontata Blackwall, 1833

MATERIAL. 1 [ [1], 13-15.VI.2008; 1 + , same locality, 1517.VI.2008; $1 \mathrm{O}^{7}$ [5], 24-25.VI.2008.

COMMENTS. This is the northernmost record of the species, which is reported from the coastal zone of the Kola Peninsula for the first time.

RANGE. West Palaearctic polyzonal.

Semljicola faustus (O. Pickard-Cambridge, 1900) MATERIAL. 1 i [2], 11-13.VI.2008.

COMMENTS. This is one of the northernmost records of the species.

RANGE. Fennoscandian-Siberian boreal.

Tiso aestivus (L. Koch, 1872)

MATERIAL. 1 ㅇ [12], 25.VI.08.

RANGE. Holarctic polyzonal.
Walckenaeria cuspidata Blackwall, 1833

MATERIAL. 1 i [8], 15.VI.08.

COMMENTS. This is one of the northernmost records of the species.

RANGE. Holarctic polyzonal.

Walckenaeria kochi (O. Pickard-Cambridge, 1872)

MATERIAL. 1 [8], 15.VI.08; 1 ㅇ [02], 17-20.VI.2008.

COMMENTS. This is one of the northernmost records of the species.

RANGE. Palaearctic boreo-nemoral.

\section{Fam. LYCOSIDAE (1)}

Pardosa palustris (Linnaeus, 1758)

Lycosa tarsalis. - Fedotov, 1912: 468.

Pardosa palustris. - Vasilyeva, Nekhaev, 2009: 33-34.

MATERIAL. $1 \sigma^{7}$ [6], 17-20.VI.2008; 7 우, $3 \sigma^{7} \sigma^{7}$, same locality, 24-25.VI.2008; 2 우, 3 ○ $^{7} \sigma^{7}$ [3], 20-22.VI.2008; $20^{7} \sigma^{7}$ [4], 20-22.VI.2008; 4 우, 2 O $^{7}$, same locality, 24-25.VI.2008; 1 +, 6 O$^{7} O^{7}$ [7], 24-25.VI.2008.

RANGE. Holarctic polyzonal.

\section{Fam. THERIDIIDAE (1)}

Steatoda bipunctata (Linnaeus, 1758)

MATERIAL. 2 우 [9], 15.VI.08.

RANGE. Holarctic.

Fam. THOMISIDAE (1)

Ozyptila trux (Blackwall, 1846)

MATERIAL. $1 \mathrm{O}^{\text {T7 }}$ [4], 24-25.VI.2008.

RANGE. Palaearctic polyzonal.

\section{Discussion}

The studied material from Bolshoy Aynov Island comprise of 95 adult specimens belonging to 17 spider species of 4 families. Two species, Pardosa palustris and Bolyphantes luteolus, were earlier recorded from the island by Fedotov [1912] and Vasilyeva \& Nekhaev [2009]. Savignia frontata is reported for the Barents Sea coast of the Kola Peninsula for the first time. Bolshoy Aynov Island is the northernmost locality of the known distribution of eight species: $B$. luteolus, $S$. frontata, Centromerus arcanus, Micrargus herbigradus, Oryphantes angulatus, Semljicola faustus, Walckenaeria cuspidata and $W$. kochi.

The highest species diversity is observed in the locality 2 where six species were found. The largest number of specimens per biotope (28) was recorded in the locality 4. Yet, representatives of the families Linyphiidae, Lycosidae, Thomisidae were found in the undershrub tundra only, whereas the theridiid Steatoda bipunctata was only found indoor.

Due to the limited material studied it is difficult to provide a detailed chorological analysis. However, the structure of spider fauna of the island is similar to those both of the Kola Peninsula coast [Tanasevitch, Ry- 
balov, 2010; Tanasevitch, Kamayev, 2011] and of the northern Norway coast [Aakra et al., 2000]. The linyphiids constitute the majority of species and individuals. The spider fauna of Bolshoy Aynov Island consists of boreal and polyzonal widespread species, except for only $O$. angulatus having a European range.

ACKNOWLEDGEMENTS. We are very grateful to Dr Andrei Tanasevitch, Centre for Forest Ecology and Production RAS, Moscow, Russia, for his consultation on spider taxonomy and helpful comments, to Dr Eugene Borovichev, the Polar Alpine Botanical Garden-Institute KSC RAS, Kirovsk, Russia, for his help in plant identification. Special thanks go to the administration of Kandalaksha Nature Reserve for the opportunity to collect spiders in Bolshoy Aynov Island. The study was supported in part by the President Program for the Support of Leading Scientific Schools (Yu. I. Chernov).

\section{References}

Aakra K., Hanssen O., Ødegaard F. 2000. A collection of spiders (Araneae) from palsa bogs in the vicinity of Vardø, northern Norway // Fauna norv. Vol. 20. P.43-47.

Aleksandrova V.D. 1977. [Geobotanical subdivision of the Arctic and Antarctic]. L.: Nauka Publ. 189 p. [in Russian].

Bereslina I.P. 1987. [Plants and waterfowl birds of marine islands of the Kola Subarctic]. L.: Nauka Publ. 200 p. [in Russian].

Fedotov D.M. 1912. [To the spider fauna of Murman and Novaya Zemlya] // Annu. Mus. Zool. Acad. Sci. St.-Petersb. Vol.16 (1911). P.449-474 [in Russian].

Tanasevitch A.V., Kamayev I.O. 2011. [Spiders of the Kola Peninsula, Russia (Arachnida: Aranei)] // Caucasian Entomol. Bull. Vol.7. No.1. P.7-32 [in Russian, with English summary].

Tanasevitch A.V., Rybalov L.B. 2010. On spiders from the tundra zone of the Kola Peninsula, Russia (Arachnida: Aranei) // Arthropoda Selecta. Vol.19. No.1. P.41-56.

Vasilyeva A.A., Nekhaev I.O. 2009. [To the ecology of spider Pardosa palustris (Aranei, Lycosidae) in Murmansk Area] // Problemy morskoy paleoekologii i biogeografii v epokhu globalnikh izmeneniy. M.: GEOS. P.33-34 [in Russian].

Responsible editor D.V. Logunov 